\title{
Isolation and Identification Avian Influenza A non-H5 Virus from Muscovy Duck (Cairina moschata) at Two Live Bird Markets in Surabaya
}

\author{
A.T. Soelih Estoepangestie ${ }^{1}$, Deya Karsari ${ }^{*}$. Adi Prijo Rahardjo ${ }^{3}$, Retno Sri Wahjuni ${ }^{4}$, \\ Suwarno $^{3}$ \\ ${ }^{1}$ Department of Veterinary Public Health, Faculty of Veterinary Medicine Universitas \\ Airlangga, Surabaya, Indonesia. \\ ${ }^{2}$ Faculty of Veterinary Medicine Universitas Airlangga, Surabaya, Indonesia. \\ ${ }^{3}$ Department of Veterinary Microbiology, Faculty of Veterinary Medicine Universitas \\ Airlangga, Surabaya, Indonesia. \\ ${ }^{4}$ Department of Veterinary Basic Medicine, Faculty of Veterinary Medicine Universitas \\ Airlangga, Surabaya, Indonesia. \\ *Corresponding author: deyaka88@gmail.com
}

\begin{abstract}
The aim of this study was to isolate and identify Avian Influenza A non-H5 virus from muscovy duck at two live bird markets in Surabaya. Muscovy duck is the natural reservoir of Avian Influenza virus, in which all of the 16 HA subtypes and 9 NA maintained. The Avian Influenza virus replicates in intestinal tract of the reservoirs, causing the high amount of virus shed in the faeces. This study is an observational descriptive study, using non random sampling method of determined samples. The method used in this study were Hemagglutination Inhibition (HI) test and Enzyme Linked Immunosorbent Assay (ELISA) test. Avian Influenza A non-H5 virus was identified 19.23\% (5 samples out of 26) in PS1 and 23.34\% (7 samples out of 30) in PS2. This finding shows that Avian Influenza A non-H5 virus could be isolated and identified from muscovy duck at two live bird markets in Surabaya.
\end{abstract}

Key words: Avian Influenza, Muscovy duck, Influenza A non-H5, Live bird markets.

\section{INTRODUCTION}

Avian Influenza is a viral disease in poultry that is infectious and zoonotic, and can even cause death. Avian Influenza is categorized as Office International des Epizooties (OIE) in list A, because it spreads rapidly across national borders. Avian Influenza outbreak also has an impact on socio-economic, public health and international trade, especially poultry products and their processed products (Alexander, 2000).

Waterfowl such as ducks, enthogs, and geese are natural hosts for the Avian Influenza virus, where the influenza A virus is in a balanced state and does not cause disease. Of all the 16 HA subtypes and 9 NA subtypes present in the waterfowl population, in these birds the virus replicates, especially in the digestive tract, so that viruses with high titer are present in feces. (Mahardika et al, 2005).

The principle of waterfowl as a natural reservoir, the Avian Influenza virus is sometimes transmitted to other animals, including mammals and domestic farms causing infection transmission and outbreaks, through adaptation of viral mutations or genetic reassortment (de Jong and Tran, 2006).

Live poultry markets, especially those that are permanent in nature, where unsold poultry 
will stay overnight in the market, has been known to be able to strengthen and store the Avian Influenza virus in these birds. Virus isolation rates in such markets are generally high compared to those detected in commercial poultry farms, so this market is an ideal setting for Avian Influenza virus surveys (Peiris, 2007).

The process of buying and selling live poultry in traditional markets in Indonesia is not much different from markets in neighboring

\section{METHODS}

The tools used in this study were bunsen burners, refrigerators, vortex mixers, tweezers, scissors, suction pipettes, pasteur pipettes, autoclaves, sterile microtubes, aluminum foil, beaker glasses, erlenmayer flasks, venoject tubes, petri dishes, $1 \mathrm{ml}$ syringes and needle, test tube rack, centrifuge tube, centrifuge, incubator, egg candler, ice box, shaker, conical tube, microplate "V", microplate ELISA, micropipette multichanel yellow tips, blue tips, gloves and masks, cotton buds and ELISA Reader.

The materials used in this study, 9-11 days of age TAB are SAN (Specific Antibody Negative), H5N1 antigen and antiserum (chicken) and H5N2 antiserum (duck) from the Virology Laboratory, Department of Veterinary Microbiology, Faculty of Veterinary Medicine, Airlangga University, Surabaya., Streptomycin Sulfate, PenicillinG, PZ $0.9 \%$ or physiological $\mathrm{NaCl}$, chicken erythrocytes $0.5 \%$, sterile aquadest, tepol, alcohol 70\% Formaldehyde PA 37\%, Etylen Diamine Tetra Acetic Acid (EDTA) countries, even if the poultry that is sold is not known about the origin of the husbandry or the health status of the poultry. Live poultry sellers have the habit of mixing multi-species birds in one place, making the spread of the Avian Influenza virus easy. This makes traditional markets one of the critical points for the spread of the Avian Influenza virus in Indonesia (Jaelani, 2008).

Carbonate Buffer, Washing Buffer, Antiduck Conjugate, Buffer Substrate.

Samples were randomly selected enthog cloaca swabs. The swab taken can come from an enthog that is anchored at the market or from outside the area, namely faeces in the shipping box in a car or truck. The cloacal swab was performed using a sterile cotton bud and then inserted into a microtube containing PZ containing antibiotics.

\section{Virus Isolation}

Virus isolation begins with the preparation of incubated TAB aged 9-11 days, then all TABs are disinfected with $70 \%$ alcohol. The virus suspension resulted from 0.1-0.2 ml cloacal swab is injected with a syringe into the allantoic liquid through a hole that has been made in the air cavity area about $1 \mathrm{~cm}$ deep and then covered with a plaster. Eggs were incubated at $37^{\circ}$ and observed daily for embryo mortality. Allantoic fluid from eggs whose embryos died were tested with the HA test, if positive, where at the highest dilution it can still agglutinate erythrocytes, i.e. at titer greater than and equal to 24 , allantoic fluid is 
harvested. Furthermore, virus identification was carried out using the HI test (OIE, 2008). Isolates whose test results were negative were followed by the indirect-ELISA test.

\section{Inhibition Test Hemagglutination (HI)}

\section{Microtechnic}

The steps in the microtechnical HI test, starting with inserting $0.025 \mathrm{ml}$ of $\mathrm{PZ}$ into each "V" microplate well, then adding $0.025 \mathrm{ml}$ of $\mathrm{AI} / \mathrm{H} 5 \mathrm{~N} 1$ antiserum into the first hole and homogenizing it, after that transfer $0.025 \mathrm{ml}$ to the second hole and homogenize, continue until the hole Finally, remove $0.025 \mathrm{ml}$ from the last hole, then add $0.025 \mathrm{ml}$ of the 4 HA unit viral antigen to each hole and leave it for 30 minutes at room temperature. The next step is to add $0.05 \mathrm{ml}$ of $0.5 \%$ chicken erythrocyte per hole, shake gently and leave for 30 - 40 minutes at room temperature. $\mathrm{HI}$ titer is stated positive if there is agglutination barrier at serum dilution greater than and equal to $1 / 16$ or $2^{4}$ (OIE, 2008).

\section{Elisa Indirect Test}

A total of $100 \mu 11$ HA units of inactivated Avian Influenza virus from the isolates to be examined and the Avian Influenza virus (BL-3) as positive control antigens and negative controls were derived from allantois liquid $\mathrm{TAB}$ which was SAN, attached to each microplate well using carbonate buffer $\mathrm{pH} 9,6$ and incubated at $4^{\circ} \mathrm{C}$ for overnight (18 hours). Plate wells were washed three times with washing buffer (NaCl-Tween) and then blocked with $200 \mu \mathrm{l}$ of buffer blocking, and incubated at $37^{\circ}$ $\mathrm{C}$ for one hour. Next, the plates were washed and then added with $100 \mu \mathrm{l}$ of duck antiserum from the vaccination with Avian Influenza H5N2 virus which had been diluted 1:100 with solvent buffer and incubated at $37^{\circ} \mathrm{C}$ for one hour. As a comparison, a positive control antiserum was used as a result of the $\mathrm{H} 5 \mathrm{~N} 2$ Avian Influenza virus vaccination and negative controls. After that, washing was done, added with $100 \mu$ l of goat anti-duck conjugate labeled with AP enzyme with a dilution of $1 / 2500$ in the solvent buffer at each well, and incubated at the same temperature and time. After incubation, washing was carried out again and added with p-NPP substrate $10 \mathrm{mg}$ p-NPP in $10 \mathrm{ml}$ buffer substrate and added in each well as much as 100 $\mu \mathrm{l}$ and incubated in a dark room at room temperature $37^{\circ} \mathrm{C}$ for 30 minutes. The infiltration was then read on an ELISA reader with a wavelength of $405 \mathrm{~nm}$ (Kick et al., 1993; Rowe et al., 1999).

\section{RESULTS AND DISCUSSION}

Table 1.Percentage of Isolation and Identification Results of Cloaca Enthog Swab Samples Sold in Two Live Poultry Markets in Surabaya with HI Test and Elisa Test

\begin{tabular}{cccccccccc}
\hline Pasar & Total & \multicolumn{2}{c}{ HI Positif } & \multicolumn{2}{c}{ HI Negatif } & \multicolumn{2}{c}{ Elisa Positif } & \multicolumn{2}{c}{ Elisa Negatif } \\
& Sampel & $\sum$ & $\%$ & $\sum$ & $\%$ & $\sum$ & $\%$ & $\sum$ & $\%$ \\
\hline PS1 & 26 & 13 & 50 & 13 & 50 & 5 & 19,23 & 8 & 30,76 \\
& & & & & & & & & \\
PS2 & 30 & 14 & 46,67 & 16 & 53,34 & 7 & 23,34 & 9 & 30 \\
\hline Total & 56 & 27 & 48,21 & 29 & 51,78 & 12 & 21,42 & 17 & 30,35 \\
\hline
\end{tabular}

Information :

PS1: market 1; PS2: market 2; $\sum$ : total; \%: percentage 
Table 1.The results showed that 13 of the total 26 samples of PS1 tested positive for HI, so that the percentage of $50 \%$ of Avian Influenza H5 virus was obtained, while the results of the $\mathrm{HI}$ test were negative as many as 13 samples with a percentage of 50\%. Elisa test results for PS1, there were 5 positive samples and 8 negative samples with the respective percentages of $19.23 \%$ and $30.76 \%$. PS2 14 samples from 30 positive samples of Avian Influenza $\mathrm{H} 5$ virus with a percentage of 46.67\%, and 16 samples of HI negative with a percentage of $53.34 \%$, the elisa test results for PS2 7 samples were positive with a percentage of $23.34 \%$ and 9 samples were negative and the percentage is $30 \%$.

Table 2.Percentage of AI / H5, AI / Non-H5, and Non-Influenza Virus Isolates from Cloacal Enthog Swab Samples Sold in Two Live Poultry Markets in Surabaya

\begin{tabular}{|c|c|c|c|c|c|c|c|}
\hline \multirow[t]{2}{*}{ Pasar } & \multirow{2}{*}{$\begin{array}{c}\text { Total } \\
\text { Sampel }\end{array}$} & \multicolumn{2}{|c|}{ AI/ H5 } & \multicolumn{2}{|c|}{ AI/ Non-H5 } & \multicolumn{2}{|c|}{ Non-Influenza } \\
\hline & & $\sum$ & $\%$ & $\sum$ & $\%$ & $\sum$ & $\%$ \\
\hline PS1 & 26 & 13 & 50 & 5 & 19,23 & 8 & 30,76 \\
\hline PS2 & 30 & 14 & 46,67 & 7 & 23,34 & 9 & 30 \\
\hline Total & 56 & 27 & 48,21 & 12 & 21,42 & 17 & 30,35 \\
\hline
\end{tabular}

Information :

PS1: market 1; PS2: market 2; $\sum$ : total; \%: percentage

Table 2 shows that PS1 can be isolated and identified as many as 13 samples of the Avian Influenza $\mathrm{H} 5$ virus from a total of 26 samples with a percentage of $50 \%$, while the samples showing positive Avian Influenza A non-H5 are 5 of the total 26 samples with a percentage of $19.23 \%$. PS2, there were 14 positive samples of Avian Influenza H5 with a percentage of $46.67 \%$ and 7 samples of positive Avian Influenza A non-H5 samples from a total of 30 samples, so the percentage was $23.34 \%$. The non-influenza samples from PS1 were 8 samples with a percentage of $30.76 \%$ and PS2 were 9 samples with a percentage of $30 \%$. The total in Surabaya was $48.21 \%$, namely 27 samples from 56 positive samples of Avian Influenza A H5, 12 samples from 56 positive samples of Avian Influenza A Non-H5 viruses with a percentage of $21.42 \%$, and 17 samples from a total of 56 samples including non-virus Influenza with a percentage of $30.35 \%$.

This study proved that in two live poultry markets in Surabaya, non-H5 Avian Influenza A viruses could be found, with a percentage of $19.23 \%$ in PS1 and $23.34 \%$ in PS2. Referring to WHO (2004) and OIE (2008), the HPAI virus is not only $\mathrm{H} 5$ but also $\mathrm{H} 7$, while $\mathrm{H} 9$ is a notifiable influenza virus that needs to be monitored. Avian Influenza virus subtype H9 has spread throughout Asia and the Middle East, this virus subtype is LPAI, but if it occurs in combination with other pathogens it can cause severe respiratory disease in livestock (Alexander, 2000).

Isolates whose $\mathrm{HI}$ test results showed negative results were continued using the indirect-ELISA test. According to Pourbaksh (1999) specific virus types against antibodies can be detected using the indirect-ELISA test by 
detecting the presence of nucleoproteins (NP) and Matrix $(\mathrm{M})$ contained in the influenza A virus envelope, so this test is to determine that those that show negative HI test results include in the influenza A virus. Isolates that show negative results in both the indirect-ELISA and $\mathrm{HI}$ tests, means that these isolates are not Avian

\section{CONCLUSION}

Based on the results of the research that has been done, it can be concluded that in the two live poultry markets in Surabaya, 5 samples of Avian Influenza A Non-H5 virus were isolated

\section{REFERENCES}

Alexander, D.J. (2000): A review of avian influenza in different bird species. Vet.Micr. 74, 3-13.

CFSPH (The Center for Food Security \& Public Health). 2008. Newcastle Disease, Avian Paramyxovirus-1 Infection, Goose Paramyxovirus Infection. July 14 , 2008. www.cfsph.iastate.edu/ICAB/

de Jong M.D., Tran T.H. 2006. Avian influenza A (H5N1). Journal of Clinical Virology 35 (2006) 2-13

Jaelani, A. 2008. Peran Sentral Pasar Unggas dalam Penyebaran AI. Fokus Edisi 169 Agustus 2008. //http.www.infovet.blogspot.com/2009 /01/peran sentral-pasar-unggasdalam.html com

Kick, L. D., J. K. Skeeles, and R. W. Mcnew. 1993. Antibody detection in matched chicken sera and egg yolk samples by commercial enzyme-linked immunosorbent assay kits for
Influenza viruses, it is possible that these isolates contain Newcastle Disease (ND) virus, referring to CFSPH (the Center for Food Security and Public Health) 2008, ND virus also found in waterfowl and generally asymptomatic, but it is also secreted through feces and can last for months.

and identified from PS1 with a percentage of $19.23 \%$ and 7 samples from PS2 with a percentage $23.34 \%$.

Newcastle disease virus, infectious bronchitis virus, infectious bursal disease virus and avian reovirus. Avian Dis. 37 (3) 825-828.

Mahardika I.G.K.N., G.A.Y Kencana., M Sibang., I.B Suardana., I.B.O Winaya. 2005. Aspek Epidemiologi Virus Avian Influenza: Sifat Virus Dan Peran Berbagai Spesies Hewan Dalam Genesis Pandemi. Laboratorium Virologi., Laboratorium Patologi. Universitas Udayana. Bali.

OIE. 2008. Terrestrial Manual.Chapter 2.3.4. Avian Influenza.

Peiris, J. S. M., M.D. de Jong, Yi Guan. 2007. Avian Influenza Virus (H5N1): a Threat to Human Health. Clinical Microbiology Reviews Vol. 20, No.2, Apr.2007, p.243-267

Pourbakhsh S.A., F. Moosakhani and M. Kianizadeh. 1999. Standardization of ELISA for Detection of Avian 
Influenza Virus Antibodies. Arch. Razi Ins. (1999) 50.

Rowe, T A., R A. Abernathy, J. Hu-Primmer, W.W. Thompson, Y. Lu, W. Lin, K. Fukuda, N.J. Cox, and J.M. Ketz. 1999. Detection of antibody to avian influenza A (H5N1) virus in human serum by using a combination of serologic assays. J Clin Microbiol. 377 (4) : 937-943.

WHO. 2004. Avian influenza - fact sheet. http://www.who.int. 